\title{
The structure, composition, and threatened plants in The Kinarum Protected Forest, South Kalimantan, Indonesia
}

\author{
DODO $^{\boldsymbol{\nu}}$, SYAMSUL HIDAYAT ${ }^{\boldsymbol{\nu}}$ \\ Research Center for Plant Conservation and Botanic Gardens (Bogor Botanic Gardens), Indonesian Institute of Sciences. J1. Ir. H. Juanda No. 13 Bogor \\ 16122, West Java, Indonesia. Tel./fax.:+62-251-8322-187, ”email: dodortl@gmail.com; " widayatkbri@yahoo.com \\ Manuscript received: 20 April 2020. Revision accepted: 16 May 2020.
}

\begin{abstract}
Dodo, Hidayat S. 2020. The structure, composition, and threatened plants in The Kinarum Protected Forest, South Kalimantan, Indonesia. Biodiversitas 21: 2603-2618. Kinarum Protected Forest (Kinarum PF) is one of the remaining tropical forest areas in Tabalong District, South Kalimantan, Indonesia. It is feared that deforestation will occur in this forest due to various human activities. The research was conducted to determine the structure and composition of vegetation in Kinarum PF which several decades ago was once a forest concession area. This research also explored the existence of threatened, endemic, and protected plants. Research has been carried out using the track plot method. The total research area is 0.6 ha consisting of three transect lines with five plots measuring $20 \times 20 \mathrm{~m}^{2}$ each transect. Data were analyzed with important value index (IVI), dominance index, species diversity index, and species abundance index. The results recorded 460 specimens belonging to 121 species, 86 genera, and 43 families. Most species are from the family Lauraceae followed by Moraceae and Rubiaceae. The results also recorded 42 species included in the IUCN red list plants, eight of which are classified as threatened plants, namely Aglaia angustifolia, Artocarpus tamaran, Dracontomelon costatum, Durio dulcis, Durio kutejensis, Eusideroxylon zwageri, Myristica magnifica, and Shorea guiso. These plants have an average IVI value less than $10 \%$ and the species abundance index is close to zero. In general, the forest condition is classified as moderate with a diversity index value at each growth stage in the range of values 1-3. However, IVI of each species, especially those belonging to the threatened, endemic, and protected plants are on average low.
\end{abstract}

Keywords: Endemic, Kinarum protected forest, protected plant, structure and composition, threatened

\section{INTRODUCTION}

Indonesia comprises only 1.3 percent of the earth's land surface, it harbors a disproportionately high share of the world's biodiversity, including 11 percent of the world's plant species, 10 percent of its mammal species, and 16 percent of its bird species. The majority of these species are found in the country's forests (Sukara 2014). Indonesia is a mega-diverse country, its special insular nature along with the high number of endemic species vs. a high number of threatened species (von Rintelen et al. 2017). Based on IUCN data (www.iucnredlist.org), the number of threatened plants in Indonesia is increasing every year. In 2014 there were 408 species (IUCN 2014), 437 species in 2018 (IUCN 2018), 519 species in 2019 (IUCN 2019), and 619 species in 2020 (IUCN 2020). This condition is very worrying for the existence of Indonesian plants, because these plants will be increasingly threatened or become extinct if in the near or very near future there is no meaningful protection and rescue.

The most important conservation activity for plant diversity is in-situ conservation. However, the condition of plants in natural habitats often gets serious threats such as habitat destruction and exploitation so that plants become threatened and even extinct. Budiharta et al. (2011) reported that intrinsic biological factors and habitat loss are the most significant general threats and over-exploitation has also contributed considerably to species endangerment. Laurance et al. (2014) argued that agricultural development could trigger the loss of biodiversity through land-use change. Deforestation, is one of the highest rates of primary forest loss in the Indonesian forest. Austin et al. (2019) reported that oil palm plantations were the largest driver of deforestation over the 2001-2016 period, resulting in $23 \%$ of deforestation nationwide, The expansion of timber and other large-scale plantations together resulted in $21 \%$ of national deforestation. The expansion of smallscale agriculture and small scale mixed plantations together resulted in $22 \%$ of national deforestation. They estimate that the area impacted by logging roads was just over 350,000 ha during 2001-2016, suggesting that the total area degraded by logging activities could have been as high as $1,750,000$ hectares. In Kalimantan, oil palm plantations were the dominant driver of deforestation from 2005 to 2013. Forest conversion to grassland/shrubland was also an important driver of forest loss in Kalimantan, more than two-thirds of the area of national forest to grassland conversion in 2016 occurred in Kalimantan.

The support of ex-situ plant conservation organizations such as botanical gardens is urgently needed to save plants from the threat of extinction, because the botanical gardens carry out exploration/expeditions, collection, propagation, and cultivation. (Heywood 2011; Dosmann and Groove 2012; Krishnan and Novy 2016) The results of plant propagation will be returned to their natural habitat. For this reason, the combination of in-situ and ex-situ conservation (integrated conservation) is the most ideal strategy to save plant species from extinction (IUCN/SSC 
2014; Schwartz et al 2017; Mc Gowan 2017; Mounce et al 2017). This activity is in line with GSPC target 8 which states 'At least 75 percent of threatened plant species in $e x$ situ collections, preferably in the country of origin, and at least $20 \%$ available for recovery and restoration programs'.

Kalimantan is known as an island that has a wealth of plants (Komara et al. 2016; Sofiah et al. 2018). Kinarum Protected Forest in Tabalong District was chosen as the location of the research because according to information from the Forest Service of South Kalimantan Province, the condition of the forest is still good, although this area was once a production forest in the era of 1970 to 1990 , so it's thought to have lost a lot of species. However, based on local community information, there are still a number of commercial and threatened plant species. such as meranti (Shorea spp.), ulin (Eusideroxylon zwageri), sindur (Sindora wallichii), and jelutung (Dyera costulata) as well as fruit plants such as durian (Durio spp.) and langsat (Baccaurea spp.). Epiphytic plants such as orchids can still be found in forested areas, while other plants such as rattan are still used by the community as matting (Heriyadi 2016). Adjacent to the protected forest area there is an area developed as the Kinarum rafting ecotourism area and also some areas that have been converted into plantations by the community, this will threaten the existence of the remaining rare plants. In some forest areas such as Kinarum PF there is currently serious pressure on the presence of species directly, including emerging threats from invasive species, diseases, overharvest, habitat alteration and climate change (Mc Gowan 2017; Mounce et al. 2017; Chen and Sun 2018) or logging (Toma et al. 2017). Illegal logging in the production and protected forest areas around Riam Kinarum poses a serious threat to the sustainability of the plant species in Kinarum PF. The impact of environmental losses arising from the practice of illegal logging currently has been very well perceived by the people who live inside and outside of the Tabalong District (Basuki et al. 2013). Raes et al. (2009) stated that $56 \%$ of Kalimantan's protected lowland forests have been lost between 1985 and 2001, and forest degradation continues today.

Based on the information and facts mentioned above, the hypothesis of this study is that many plants are threatened even though diversity of plant species in Kinarum PF is expected to be low. Remaining plants, especially rare or threatened species, must be immediately saved both in-situ and ex-situ. The botanical garden is obliged to conserve endangered plants so it is necessary to know the exact data of the existence of these plant species in Kinarum PF. The structure and composition of plants in Kinarum PF is also very important to be known by the area manager in order to make a proper conservation effort. Pamoengkas et al. (2019) stated that information about the conditions of residual stands is important and urgently required for conservation efforts.

The purpose of this research is to determine the current conditions of the structure and composition of plants in Kinarum PF and to inventory the existence of threatened and or endemic plants. The results of this research are expected to be one of the references for future conservation efforts in the region, both in-situ and ex-situ.

\section{MATERIALS AND METHODS}

\section{Research area}

The research was conducted on 5-10 September 2017 at the Jaing Forest Management Resort part of the Tabalong Production Forest Management Unit (KPHP), precisely at Kinarum PF which covers 6,382 ha (Heriyadi 2016). This forest area is $1.6 \mathrm{~km}$ from the village of Kinarum, Upau Sub-district, Tabalong District, South Kalimantan Province, Indonesia. Jaing Forest Management Resort, covering the entire forest area of Murung Pudak Subdistrict and part of Upau Sub-district's forest area with an area of 21,573 ha consisting of 6,382 ha of protected forest and 15,191 ha of production forest.

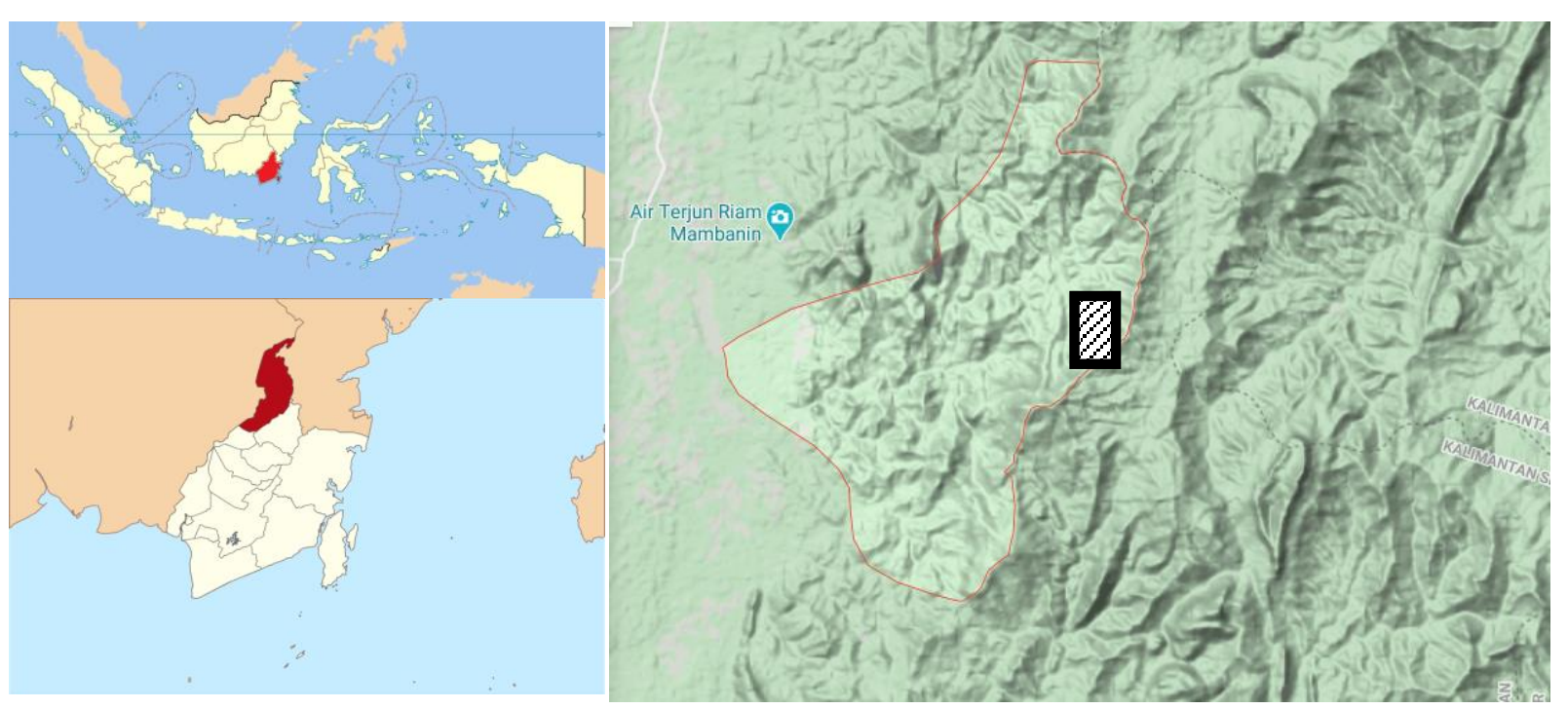

Figure 1. Research area in Kinarum Protected Forest, Upau Sub-district, Tabalong District, South Kalimantan Province, Indonesia. Kinarum PF 
The Kinarum PF region is administratively a part of the Kinarum Village, Upau Sub-district, Tabalong District, South Kalimantan Province (Figure 1). The area is in the Tabalong watershed area which is drained by two main rivers namely the Kinarum river and the Jaing river.

The research location is at an altitude of 150-280 m above sea level, located in geographical coordinate points of 0204 "90.70" S and 11565 "43.9" E. This location is part of the northern hills of the Meratus Mountains series. Topographic conditions are generally sloping with a slope ranging from $5 \%$ to $85 \%$. Soil types, in general, are red yellow podsolic complex, laterite, lithosol, and latosol. The degree of soil acidity is 5.6-6.5 and soil moisture is 45$70 \%$. According to Heriyadi (2006), the climate of this tropical forest area has an air temperature of $29^{\circ}-31^{\circ} \mathrm{C}$ and humidity of $68-93 \%$, rainfall of $1,544 \mathrm{~mm} /$ year with 117 days of rainy days. In general, Tabalong has the highest rainfall in December $(636 \mathrm{~mm})$ and the lowest rainfall occurs in September (50 mm).

This research area is a secondary forest that was 40-50 years ago managed as a forest concession area. This area is part of secondary dryland forests that were once heavily overgrown by species from Dipterocarpaceae, Moraceae, and Meliaceae. Some fruits and rattan are non-timber forest products that are still consumed by the community until now.

\section{Sampling and data}

To obtain data on the composition and structure of vegetation in the Kinarum PF area, it has been carried out through vegetation analysis activities using the track plot method. Three transect lines were made of $100 \mathrm{~m}$ each with 5 observation plots measuring $20 \times 20 \mathrm{~m}^{2}$ per lane. The distance between the transect lines is $100 \mathrm{~m}$. Each observation plot is further divided into observational subplots based on the growth stages. The objects in this research were all plant species found in the observation plot. Vegetation inventory has been carried out on sample plots that are suitable for the growth stage of $20 \times 20 \mathrm{~m}^{2}$ for tree, $10 \times 10 \mathrm{~m}^{2}$ for pole, $5 \times 5 \mathrm{~m}^{2}$ for sapling, and $2 \times 2 \mathrm{~m}^{2}$ for seedlings and or undergrowth. Each individual plant found in the entire plot was measured stem diameter at breast height (dbh) using a tape diameter, then classified whether it included trees, poles, or sapling. This dbh size is used as the basis for calculating the basal area for trees and poles. Meanwhile, specimens that have stem diameters of less than $10 \mathrm{~cm}$ (sapling and seedling) only count the number of individuals of each species in each sub-plot. The area of the research is 0.6 ha or $0.01 \%$ of the total protected area. Nicholson (in Edwin et al. 2017) stated that the sampling area ranging from $0.6-1.5$ ha in Borneo rainforest has already been represented.

The classification of growth stages in this research is: (i) Seedlings: dbh $<3$ and height $\leq 1.5 \mathrm{~m}$, (ii) Sapling: $3 \leq$ $\mathrm{dbh}<10 \mathrm{~cm}$, (iii) Pole: dbh 10-20 cm, and (iv) Tree: $\mathrm{dbh}>$ $20 \mathrm{~cm}$.

Some plant species were identified directly on the plots, while for some others identification could not be made on the plots and depended on making herbarium specimens. The herbarium specimens were then identified by reference to voucher specimens held by Herbarium Bogoriense as well as the herbarium and living plant collections in Bogor Botanic Gardens. The scientific names of plants adopted were those already in use within The Plant List.

\section{Data analysis \\ Important value index}

Data analysis using Microsoft Excel 2010 and QGIS 2.14.1-Essen. Relative Density (RD), Relative Frequency (RF), Relative Dominance (RD.), and Importance Value Indices (IVI) were calculated and analyzed according to the Dumbois-Muller and Ellenberg formula (1974). Basal area $\left(\mathrm{m}^{2}\right)$ is the area occupied by a cross-section of stem at breast height $(1.3 \mathrm{~m})=\left[3.14 \mathrm{x}(\mathrm{dbh} / 2)^{2}\right]$. Absolute values so obtained may be transcribed to relative values:

$$
\begin{aligned}
& \text { Relative density }(\%)=\quad \begin{array}{l}
\text { No. of individuals of a species } \\
- \text { Total no. of individuals in sample }
\end{array} \\
& \text { Relative dominance }(\%)= \\
& \begin{array}{l}
\text { Basal area of a species } \\
\text { Total basal area in sample }
\end{array} \\
& \text { Relative frequency }(\%)=\quad \begin{array}{l}
\text { Sampling units containing a species } \\
\text { Sum of all frequencies }
\end{array}
\end{aligned}
$$

Importance Value Index (IVI) for a species is the sum of its relative density, relative dominance, and relative frequency. The IVI values have been helped to understand the ecological significance of the species in community structure (Premavani et al. 2014).

\section{Diversity index and dominance species}

Shannon's Diversity Index (H') was calculated to quantify the vegetation structure (Magurran 1988):

$$
\begin{aligned}
& \mathrm{H}:-\sum(n i / N) \log (n i / N) \\
& \text { ni : number of individuals of the i species } \\
& \mathrm{N}: \text { total number of individuals of all species }
\end{aligned}
$$

The index was calculated for each of the four growth stages (seedling, sapling, pole, and tree). Diversity criteria according to Barbour et al. (1987), vegetation has a high level of diversity if the Diversity Index $\mathrm{H}$ '> 3 . While categorized as moderate if the value of $\mathrm{H}^{\prime}=1-3$, and said to be low if the value of $H^{\prime}<1$.

The abundance of a species was analyzed using the species abundance index (e) (Odum and Barrett 2004),

$$
\mathrm{e}=\mathrm{H} /(\log \mathrm{s})
$$

Where:

e : Species Abundance Index: (e value: $0-1 ; 1$ : all species are abundant)

$\mathrm{H}$ : Index of species diversity

$\mathrm{s} \quad$ : Number of species

Dominance in a community and plant regeneration stage were analyzed using the Dominance Index (Ds) (Odum and Barrett 2004), 
$\mathrm{Ds}=(\mathrm{ni} / \mathrm{N})^{2}$

Where:

Ds : Domination Index

ni : importance value of the-i species

$\mathrm{N}$ : total importance

On the basis of ecological dominance (Ds) in a community the species are grouped into three categories (Krebs 1999): (i) $0.00<\mathrm{Ds}<0.30=$ low dominance, (ii) $0.30<$ Ds $<0.60=$ intermediate dominance, and (iii) $0.60<$ Ds $<1.00=$ high dominance.

\section{Conservation status}

Determining species conservation status is based on data from the International Union for the Conservation of Nature and Natural Resources (IUCN) available on its official website, i.e. http: //www.iucnredlist.org/search. A plant is declared as threatened species if it has been entered into the International Union for the Conservation of Nature and Natural Resources (IUCN) category which is Critically Endangered (CR), Endangered (EN), or Vulnerable (VU). Meanwhile, species declared as endemic plants in Kalimantan refer to the Kalimantan Endemic Flora book (Sidiyasa 2015) and as protected plants nationally refer to the Minister of Environment and Forestry of the Republic of Indonesia Regulation No. 20 of 2018 concerning Protected plant and animal species and Republic of Indonesia Government Regulation No. 7 of 1999 concerning Preservation of plant and animal species

\section{RESULTS AND DISCUSSION}

\section{Structure and composition}

Based on the results of the inventory, 632 specimens have been obtained which are included in 121 species, 87 genera, and 44 families (Table 1). This shows that Kinarum $\mathrm{PF}$ is inhabited by many plant species so that it can be stated that the condition of Kinarum PF in terms of plant species richness is quite good with the diversity index value obtained more than one. The 632 specimens were divided into four growth stages, namely 240 tree stages (67 species, 48 genera, 24 families), 81 pole stages (35 species, 28 genera, 17 families), 113 sapling stages (48 species, 39 genera, 23 families), and 198 stages of seedlings or

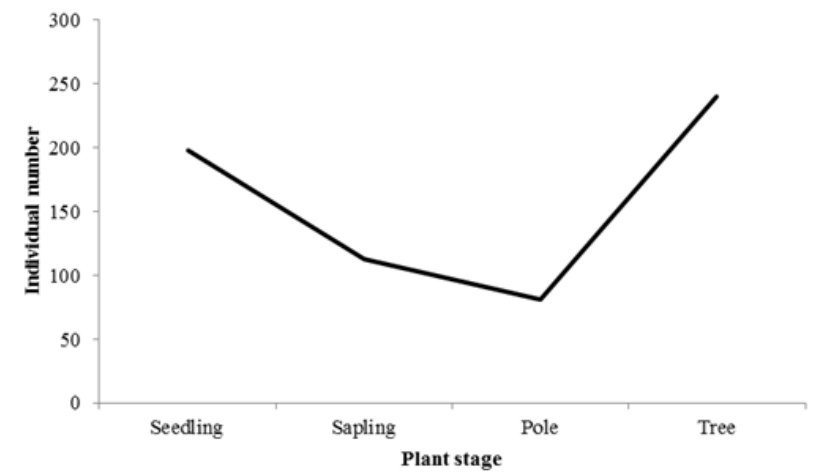

A undergrowth (35 species, 33 genera, 26 families). All plant species found can be seen in Table $\mathrm{S} 1$.

The structure of vegetation in Kinarum PF is generally seen in Figure 2. Figure 2.A shows the structure of vegetation when all types of plant habitus are included, while Figure 2.B. is a vegetation structure only for tree habitus types. Figure 2.A. looks like U-shaped while picture 2.B. looks closer to the letter J. Both structures are viewed from the aspect of regeneration is not good, because the number of young plants is smaller than the number of tree stages. This structure is quite risky if growth disturbance occurs at the tree stage and stunted growth of young plants either due to natural factors or human and animal factors. A good vegetation structure to ensure the continuity of plant regeneration in forest areas is inverted J-shaped. Inverted J-shaped patterns have shown good reproduction and potential recruitment of the species (Todou et al. 2018).

Although the number of trees appears to be more than other stages of growth, some species actually originate from pioneer species such as Macaranga spp, Malotus spp. and Ficus spp. Macaranga is a fast-growing pioneer species that may regenerate from seed banks which are abundant in the forest floor in the rain forests (Sadili and Kartawinata 2016). Macaranga spp. are also quite abundant although not many seedlings were planted (Komara et al. 2016). Thus there is still hope for continuity of regeneration for tree-type habitus even if it only comes from a pioneer species. Unfortunately, these pioneer species will not grow as large as primary wood plants. At the species level, big sized trees from Dryobalanops and other Dipterocarpaceae with small numbers of individuals presented higher values of IVI than pioneer species which had a larger number of individuals with smaller sized DBH.

Table 1. Recapitulation of species and number of specimens found at each vegetation growth stages

\begin{tabular}{lcccc}
\hline \multirow{2}{*}{ Growth stage } & \multicolumn{4}{c}{ Quantity } \\
\cline { 2 - 5 } & Species & Genus & Family & Specimen \\
\hline Tree & 67 & 48 & 24 & 240 \\
Pole & 35 & 28 & 17 & 81 \\
Sapling & 48 & 39 & 23 & 113 \\
Seedling/undergrowth & 35 & 33 & 26 & 198 \\
Total & 121 & 87 & 44 & 632 \\
\hline
\end{tabular}

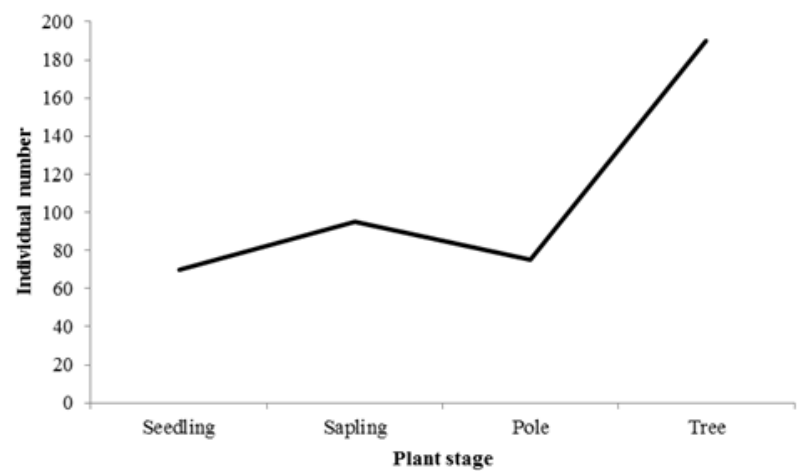

B

Figure 2. Vegetation structure of Kinarum Protected Forest. A. Vegetation structure for all habitus type, B. Vegetation structure for only tree habitus 
There are eight plant species found at all stages of growth, namely Aidia racemosa, Antidesma montanum, Artocarpus lanceifolius, Dehaasia turfosa. Diplospora malaccense, Dryobalanops lanceolata, Ficus serrata, and Xanthophyllum vitellinum. In general, the eight plant species showed good regeneration in Kinarum PF. A plant species is said to have good regeneration if it is present at all stages of growth (Zulkarnaen et al. 2015). However, when viewed based on the number of individuals at each stage of growth it would seem that for their survival, in general, these species are not ideal. From Figure 3, we can see an example of the structure of four plant species in which three of them are species belonging to the Least concern (LC) plant category according to the IUCN red list. Three LC categories, namely Aida racemosa, Antidesma montanum and Dryobalanops lanceolata have less than ideal structures compared to Diplospora malaccense structures. Aida racemosa has a structure close to the letter $\mathrm{L}$ which means it is better than the two other LC species. Antidesma montanum has a structure that tends to form zigzag while Dryobalanops lanceolata has a structure shaped J. Dryobalanops lanceolata has a high risk for failure to regenerate properly due to the relatively small number of tillers compared to the number of stages of the tree. If these small tillers are stunted while large trees are harvested illegally, the risk of extinction of D. lanceolata in Kinarum PF is very high. The relatively ideal potential for species survival is actually demonstrated by Diplospora malaccense whose structure leads to an inverted $\mathrm{J}$ shape indicating good regeneration (Astbha et al. 2019; Todou et al. 2018).

The number of species found for each family can be seen as shown in Figure 4. Families represented by 10 or more species in sequence are Lauraceae (13 species), followed by Moraceae (11 species), and Rubiaceae (10 species). Differences in species numbers are due to differences in tolerance to habitat factors such as slope, altitude, soil characteristics, and species distribution. Each species has different tolerance levels that can grow or live in a particular environment (Edwin et al. 2017). Topographical habitat plays an important role in structuring tree species. Relative elevation and slope convexity are the most important variables for predicting the presence or absence of a species. Soil type is another factor that is frequently associated with topography and can control tree distribution. This indicates that the three families have a high tolerance and adaptation to environmental factors in Kinarum PF. The Lauraceae is one of the largest and important families of trees and shrubs throughout tropical and subtropical forests (Julia et al. 2009). In the mountains of South East Asia, Lauraceae species appear over a wide altitudinal range (Sri-Ngernyuang 2003). The Lauraceae also are of major ecological and economic importance in Southeast Asia as they comprise a major part of many forests in the region (de Kok 2017). The second-highest number of species found is Moraceae. Rahmah et al. (2015) found something similar in Bukit Dua Belas National Park. They found Moraceae was the richest family (11 sp) that Ficus fistulosa had the highest density (24 trees/ha). Moraceae has many species that can grow in various habitats such as Ficus spp and Artocarpus spp. Lauraceae and Moraceae were also found as families with dominant species in the study of Edwin et al. (2017) in Wehea Protected Forest, Kutai, East Kalimantan. While Ling and Yulia (2012) in their research in Semenggoh Arboretum, Sarawak, stated that Moraceae is the third dominant family after Myristicaceae and Sapotaceae. In third place, Kinarum PF is represented by Rubiaceae which has many species. Rubiaceae is the fourth family in number of species in the Angiosperms after Orchidaceae, Asteraceae, and Leguminosae. The Rubiaceae is a cosmopolitan family, predominantly pantropical, and with a small portion of species of extratropical distribution (Delprete and Jardim 2012).

The highest number of specimens in Kinarum PF by family is Rubiaceae (91 specimens). Rubiaceae is well represented at all layers of tropical vegetation, with all kinds of habits, as herbs, shrubs, lianas, and from small trees to tall canopy trees, and all dimensions (Delprete and Jardim 2012). When viewed based on the strata, the highest number of specimens at the tree stage is Euphorbiaceae (46 specimens). Research by Kessler et al. (2005) in Napu Valley show similar results for dominant plant families based on their strata, stating that Euphorbiaceae, Rubiaceae, and Myristicaceae were the most common forest tree families in the forest gardens. Euphorbiaceae was also the dominant family in the secondary forest. In Kinarum PF, Euphorbiaceae becomes the dominant family because it is represented by many pioneer species from Macaranga and Malotus. Meanwhile, for the pole stage, the highest number of specimens was Moraceae (18 specimens), for the sapling stage was Rubiaceae (29 specimens), and for the seedling stage was Tectariaceae (87 specimens). As has been said above that Rubiacea and Moraceae are two species-rich and cosmopolitan families, this is also shown by the results of Almulqu et al. (2018) on Mount Mutis for Moraceae and in Napu Valley Forest, Lore Lindu (Kessler et al. 2005) for Rubiaceae. For seedlings or undergrowth, the family of ferns dominates Kinarum PF. Tectariaceae is the dominant family represented by the genus Tectaria followed by other ferns of Schizaeaceae namely Lygodium circinnatum. Tectaria is the largest fern genera, comprising 150-210 mostly tropical species (Zhang et al. 2017). Even in Kalimantan, the root of Tectaria is used by the Tomun Dayak tribe as one of the traditional medicines (Santoso et al. 2018). Meanwhile, $L$. circinatum is widely used as handicraft materials for household tools and traditional Dayak bags.

The highest number of specimens by species is at the tree stage is Dryobalanops lanceolata (18 specimens), at the pole stage is Dehaasia turfosa (10 specimens), at the sapling stage is Memecylon oleifolium (10 specimens), and at the seedling stage is Tectaria incisa (87 specimens). Dryobalanops lanceolata is widespread and common, but outside the protected areas the species is threatened by habitat loss and conversion, driven by the expansion of agriculture in Borneo (Bodos et al. 2019). Dryobalanops lanceolata was an endemic plant of Kalimantan but common and widespread growing in the Kinarum forest area. However, D. lanceolata is one of the plant species 
from the Dipterocarpaceae family which has several medicinal purposes such as mouth ulcers, abscesses, boils, and cold sores (Kuspradini et al. 2018). Meanwhile, Sidiyasa (2015) noted D. turfosa as one of the endemic plants of Kalimantan. Dehaasia turfosa in secondary forests usually present as a pre-disturbance remnant tree (http: //www.asianplant.net). At the sapling stage, $M$. oleifolium was obtained as the plant with the highest number of specimens. Although $M$. oleifolium is not included in Kalimantan endemic plants such as $D$. lanceolata and D. tufosa, in the Singapore flora checklist this species is stated as a critically endangered plant (Chong et al. 2009). Furthermore, T. incisa is an undergrowth which dominates the Kinarum PF region. This species is a common fern group found in Kalimantan and even Komara et al. (2016) found also in the coal mining area in Kutai, East Kalimantan.

\section{Important Value Index (IVI)}

In this research, the largest IVI at the tree stage was Dryobalanops lanceolata $(\mathrm{IVI}=46.36)$, at the pole stage was Dehaasia turfosa $($ IVI $=32.99)$, at the sapling stage was Diplospora malaccensis (IVI $=13.30)$ and at the stages, seedlings are Tectaria incisa (IVI = 63.29). Kinarum PF is dominated by D. lanceolata trees because this species has a greater diameter, density, and frequency compared to other species. This dominance shows the high adaptability of the species to its habitat. Krebs (1994) stated that the success of each species to occupy an area is influenced by its ability to adapt optimally to all physical environmental factors (temperature, light, soil structure, humidity, etc.), biotic factors (interactions between species, competition, parasitism, and etc.), and chemical factors which include the availability of water, oxygen, $\mathrm{pH}$, nutrients in the soil and others that interact with each other. In the observation area, D. lanceolata is found in relatively open areas and high light intensity. Tirkaamiana et al. (2019) said that D. lanceolata is tolerant to the availability of sunlight, they can be easily established in open planting areas that have high temperatures.

However, in this study seedling and sapling of $D$. lanceolata are difficult to find. According to Itoh et al. (1995), this is possible because about $60-70 \%$ of the scattered seeds will die. A majority of dead seedlings were killed by fallen branches or were found standing with wilted leaves, probably due to water stress. Tree seedling survival can be reduced due to drier conditions (Ismail et al. 2014). In addition according to Granados et al. (2017), Dipterocarp seeds germinate very rapidly or else perish; delayed germination and seed banks are unknown. Herbivory by invertebrates or pathogenic infection after germinated seeds may have contributed to overall mortality in the forest. IVI at the highest pole stage is occupied by Dehaasia turfosa which is a Kalimantan endemic plant. This species grows scattered in pamah forests and peat swamps. The analysis showed that $D$. turfosa has a higher density and frequency value than other species in Kinarum PF. Furthermore, the highest IVI for the sapling stage was obtained by Diplospora malaccensis.
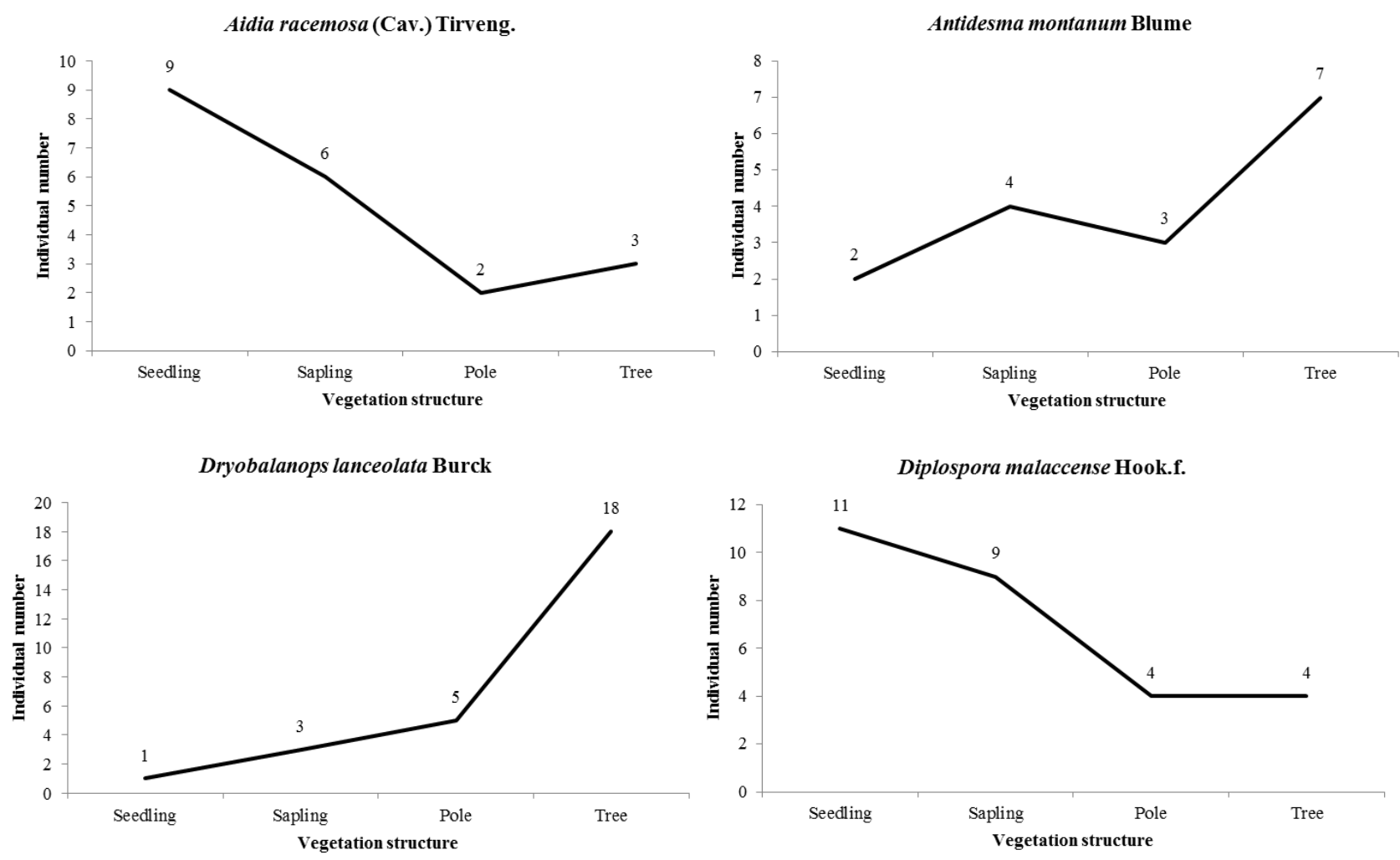

Figure 3. Four types of vegetation structure from sampling species 


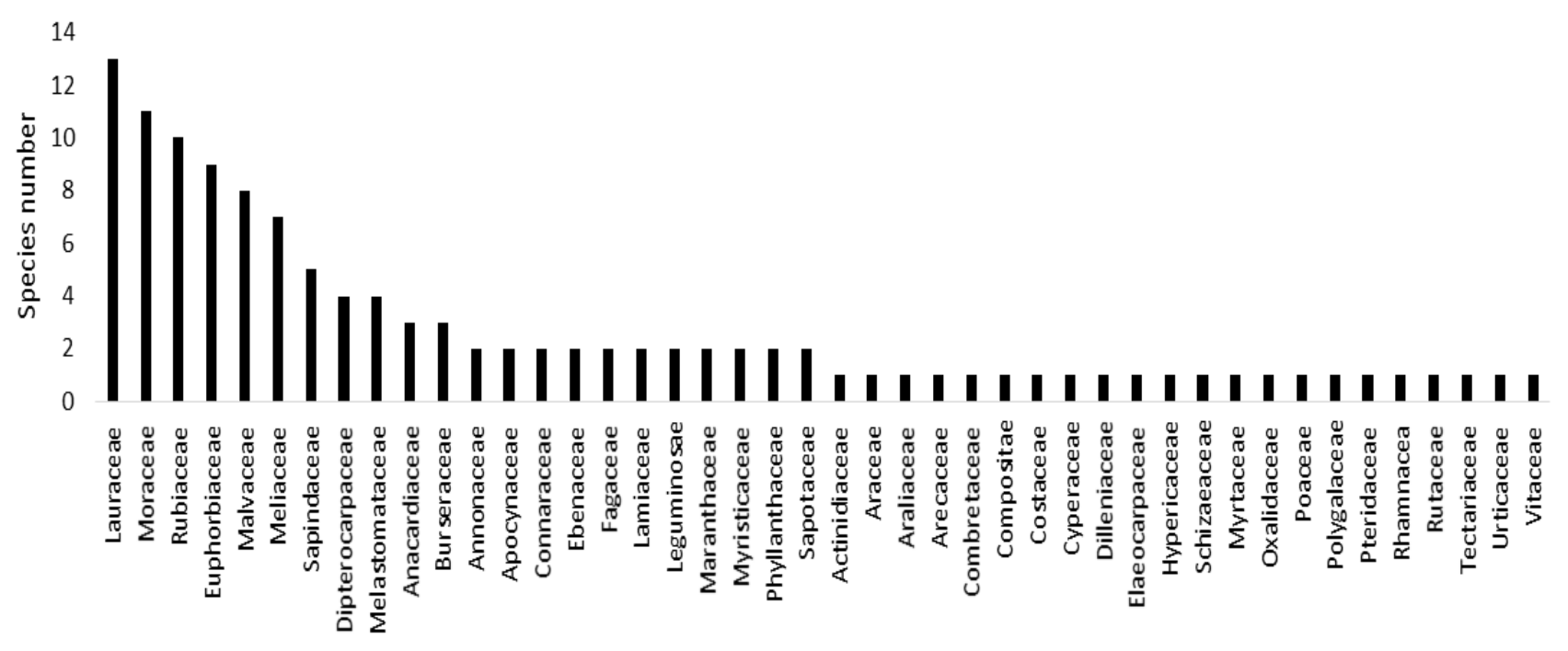

Family

Figure 4. Family composition in the research area

Sadeghi et al. (2014) reported that D. malaccensis also gave the highest importance index value for species and families in Ulu Muda Forest Reserve, Kedah, Peninsular Malaysia. The notable point was that rich successional families such as Euphorbiaceae and Rubiacea were ranked in the first and second levels of value, respectively. Meanwhile, Tectaria incisa occupies the highest IVI position for the seedling or undergrowth stage. Besides the higher density and frequency values compared to other species, this species is indeed widely distributed in almost all regions. This is very possible because Tectaria is one of the largest fern genera, it has been estimated to contain ca. 210 mostly tropical species (Zhang and Zhang 2017), one of which is T. incisa which is invasive plants.

Importance Value Index (IVI) is a quantitative parameter used to express the degree of dominance of a species in a community. Species with the greatest IVI is the most dominant species, or the ruling species (Pamoengkas et al. 2018). Based on the results of vegetation analysis, the dominant plant species obtained at each stage of growth are as follows.

\section{Tree stage}

There are five species of plants that dominate at the tree stage (Table 2), namely Dryobalanops lanceolata with an IVI value of $46.36 \%$, Macaranga bancana (21.15\%), Macaranga gigantea (20.29\%), Beilschmiedia kunstleri (19.92\%), and Ficus serrata (15.67\%). Dryobalanops lanceolata and Beilschmiedia kunstleri belong to the group of plants in the LC category (IUCN 2020). All the Beilschmiedia species of Borneo are trees, ranging in height from 8-40 m. Beilschmiedia kunstleri grows in Primary or secondary dipterocarp forest, submontane mossy forest, heath forest or kerangas forest, on mostly sandy soils, sometimes brown soils, black soils, ultrabasic or limestone. Altitude $10-800 \mathrm{~m}$, rarely up to $1300 \mathrm{~m}$
(Nishida. 2008). This is in accordance with the conditions at Kinarum PF which is at an altitude of $280 \mathrm{~m}$ with sandy soils brown to yellowish-brown. The other three species come from Macaranga spp. and Ficus which are a group of pioneer plants that individually can be found in large numbers but generally have small diameter stems. Macaranga spp., important indicators for the old secondary forest (Susanto et al. 2016) while Ficus spp. are keystone tree species in tropical forest ecosystems (Kuaraksa et al. 2012) and in which some of them are pioneers in dry habitats (Lee et al. 2013).

\section{Pole stage}

There are five plant species that dominate at the pole stage (Table 3), namely Dehaasia turfosa with IVI $32.99 \%$, Sterculia lanceolata (23.86\%) Dryobalanops lanceolata (20.52\%), Ficus consociata (20.44), and Ficus uncinata (15.76). Sterculia lanceolata grows in undisturbed to slightly disturbed (open sites) mixed dipterocarp and submontane forests up to $1000 \mathrm{~m}$ altitude. S.lanceolata is commonly found on hillsides and plays a predominant position in Kinarum PF. The same phenomenon is also found in the waterfalls of Curug Sewu, Kendal by Sunarmi et al. (2018). Meanwhile Ficus spp. still dominates at this stage which indicates that this pioneer species is quite adaptive in the Kinarum PF region. One species of which is F. uncinata according to Sidiyasa (2015), including endemic Bornean plants. Research by Widiyatno et al. (2017) in Tanjung Paku, Central Kalimantan, precisely shows Ficus spp. as the dominant plant at the seedling stage.

\section{Sapling stage}

There are three plant species at the sapling stage which have IVI $\geq 10 \%$, namely Diplospora malaccensis with IVI $=13.30 \%$, Memecylon oleifolium (11.52\%), and Aidia 
racemosa (10.64\%) (Table 4). Aidia racemosa is included in the LC category (IUCN 2020) because this species is widely used by people directly from their habitat. This plant was brought into light recently due to the ability of its roots and leaves to relieve body aches and tiredness. It is now being marketed locally as a tea or tonic for energy and overall body strength. In addition to this, it was also traditionally known to be able to cure gastric pains (Goh et al. 2017)
Seedling stage/undergrowth

Table 5. shows the two species that occupy the highest IVI for seedlings or undergrowth, namely Tectaria incisa (63.29\%) and Lygodium circinatum (13.12\%). Both of these species are groups of ferns that are quite invasive and cosmopolitan so that they control the secondary forest floor. L. circinatum is very common in Indonesia's secondary forests while $T$. incisa is found in certain regions. Neo et al. (2014) reported that Tectaria incisa has been found in Bukit Batok Nature Park and Lentor Forest.

Table 2. Dominant plants at the tree stage

\begin{tabular}{|c|c|c|c|c|c|c|c|c|}
\hline Species & $\begin{array}{c}\text { Total } \\
\text { individual } \\
\end{array}$ & $\begin{array}{c}\text { Ba } \\
\left(\mathbf{m}^{2} / \mathbf{h a}\right)\end{array}$ & $\begin{array}{l}\text { RDo } \\
(\%)\end{array}$ & $\begin{array}{c}\text { D } \\
\text { (N/ha) }\end{array}$ & $\begin{array}{l}\text { RD } \\
(\%)\end{array}$ & $\mathbf{F}$ & $\begin{array}{l}\mathrm{RF} \\
(\%)\end{array}$ & $\begin{array}{l}\text { IVI } \\
(\%)\end{array}$ \\
\hline Dryobalanops lanceolata Burck & 18 & 41.20 & 32.24 & 30.00 & 7.50 & 0.60 & 6.62 & 46.36 \\
\hline Macaranga bancana (Miq.) Müll. Arg. & 17 & 11.40 & 8.92 & 28.33 & 7.08 & 0.47 & 5.15 & 21.15 \\
\hline Macaranga gigantea (Rchb.f. \& Zoll.) Müll. Arg. & 15 & 13.24 & 10.36 & 25.00 & 6.25 & 0.33 & 3.68 & 20.29 \\
\hline Beilschmiedia kunstleri Gamble & 17 & 11.70 & 9.16 & 28.33 & 7.08 & 0.33 & 3.68 & 19.92 \\
\hline Ficus serrata $\mathrm{L}$. & 14 & 6.94 & 5.43 & 23.33 & 5.83 & 0.40 & 4.41 & 15.67 \\
\hline
\end{tabular}

Table 3. Dominant plants at the pole stage

\begin{tabular}{|c|c|c|c|c|c|c|c|c|}
\hline Species & $\begin{array}{c}\text { Total } \\
\text { individual }\end{array}$ & $\begin{array}{c}\text { Ba } \\
\left(\mathbf{m}^{2} / \mathrm{ha}\right)\end{array}$ & $\begin{array}{l}\text { RDo } \\
(\%)\end{array}$ & $\begin{array}{c}\text { D } \\
\text { (N/ha) }\end{array}$ & $\begin{array}{l}\text { RD } \\
(\%)\end{array}$ & $\mathbf{F}$ & $\begin{array}{l}\text { RF } \\
(\%)\end{array}$ & $\begin{array}{l}\text { IVI } \\
(\%)\end{array}$ \\
\hline Dehaasia turfosa Kosterm. & 10 & 0.08 & 12.80 & 16.67 & 12.35 & 0.27 & 7.84 & 32.99 \\
\hline Sterculia lanceolata Cav. & 7 & 0.06 & 9.33 & 11.67 & 8.64 & 0.20 & 5.88 & 23.86 \\
\hline Dryobalanops lanceolata Burck & 5 & 0.04 & 6.51 & 8.33 & 6.17 & 0.27 & 7.84 & 20.52 \\
\hline Ficus consociata Blume & 6 & 0.04 & 7.15 & 10.00 & 7.41 & 0.20 & 5.88 & 20.44 \\
\hline Ficus uncinata (King) Becc. & 5 & 0.03 & 5.66 & 8.33 & 6.17 & 0.13 & 3.92 & 15.76 \\
\hline
\end{tabular}

Table 4. Dominant plants at the sapling stage

\begin{tabular}{lcccccc}
\hline Species & $\begin{array}{c}\text { Total } \\
\text { individual }\end{array}$ & $\begin{array}{c}\text { D } \\
(\mathbf{N} / \mathbf{h a})\end{array}$ & $\begin{array}{c}\text { RD } \\
(\boldsymbol{\%})\end{array}$ & $\mathbf{F}$ & $\begin{array}{c}\text { RF } \\
(\boldsymbol{\%})\end{array}$ & $\begin{array}{c}\text { IVI } \\
(\boldsymbol{\%})\end{array}$ \\
\hline Diplospora malaccensis Hook.f. & 9 & 15.00 & 7.96 & 0.27 & 5.33 & 13.30 \\
Memecylon oleifolium Blume & 10 & 16.67 & 8.85 & 0.13 & 2.67 & 11.52 \\
Aidia racemosa (Cav.) Tirveng. & 6 & 10.00 & 5.31 & 0.27 & 5.33 & 10.64 \\
\hline
\end{tabular}

Table 5. Dominant plants at the seedling stage/undergrowth

\begin{tabular}{lcccccc}
\hline Species & $\begin{array}{c}\text { Total } \\
\text { individual }\end{array}$ & $\begin{array}{c}\text { D } \\
(\mathbf{N} / \mathbf{h a})\end{array}$ & $\begin{array}{c}\text { RD } \\
(\boldsymbol{\%})\end{array}$ & $\mathbf{F}$ & $\begin{array}{c}\text { RF } \\
(\boldsymbol{\%})\end{array}$ & $\begin{array}{c}\text { IVI } \\
(\boldsymbol{\%})\end{array}$ \\
\hline Tectaria incisa Cav. & 87 & 145.00 & 43.94 & 0.80 & 19.35 & 63.29 \\
Lygodium circinatum (Burm. f.) Sw. & 10 & 16.67 & 5.05 & 0.33 & 8.06 & 13.12 \\
\hline
\end{tabular}

Table 6. Index of dominance. diversity. abundance. and density of vegetation species at the growth stage in Kinarum PF

\begin{tabular}{lcccc}
\hline Uraian & Tree & Pole & Sapling & Seedling \\
\hline Dominance index (C) & 0.051 & 0.046 & 0.030 & 0.120 \\
Diversity index (H) & 1.504 & 1.443 & 1.605 & 1.259 \\
Index of abundance $(e)$ & 1.047 & 0.558 & 0.616 & 0.836 \\
Density (specimen/ha) & 400 & 135 & 188.33 & 330 \\
\hline
\end{tabular}


Based on the analysis of vegetation, dominance index, diversity index, index of abundance, and species density have been obtained at each stage of tree, pole, sapling and seedling growth (Table 6). Dominance index (C) is used to determine the level of dominance of a species in a forest area. In the Simpson index, there are several criteria in determining the value of the dominance index. $\mathrm{C}=0$ is low dominance, meaning that there are no species that dominate other species while $\mathrm{C}=1$ is high dominance, meaning that there are species that dominate other species (Krebs 1999). Based on the dominance index, it can be determined the form of concentration of dominant vegetation species in a stand. The results of the calculation of the dominance index indicate the value of $\mathrm{C}$ at each stage of growth is almost 0 (Table 6), meaning that in this forest in general no one species dominates the other species. The nearly zero values correspond to low diversity or more homogeneous plant ecosystems (Karyati et al. 2013). When viewed at each stage of growth are as follows Dryobalanops lanceolata occupies a dominant position at the tree stage with a value of $\mathrm{C}=0.024$, Dehaasia turfosa at the pole stage with a value of $\mathrm{C}=0.012$, Diplospora malaccensis at the sapling stage with a value of $\mathrm{C}=0.004)$, and Tectaria Incisa with a value of $\mathrm{C}=0.100$. Dominant species are species that can utilize the environment they occupy more efficiently than other species in the same place. The ability of a species to influence and control over a community is by a large number of species, the size, and control of the space, reflected in the value of its dominance.

Diversity index $(\mathrm{H})$ is a description of the level of species diversity within a community that can be used to express the relationship of species abundance in the community. According to Pamoengkas et al. (2018), species diversity can also be used to express community structure and measure community stability. The results of the analysis showed that the index of species diversity at the sapling stage was 1.605 . This value is higher than the index value at the tree (1.5), pole (1.4), and seedling stages (1.3). This value is indeed still smaller than the results of research in other Kalimantan lowland forests. The results of the study by Pamoengkas et al. 2019 in the production forest on logged-over forest areas in Central Kalimantan, shows the average index at all stages has values $>3$. Similarly the results of Sofiah et al. (2018) in the Besiq Bermai East Kalimantan forest, the forest area was a primary forest that started undergoing degradation and becoming a secondary forest, which shows a value of $\mathrm{H}>$ 3. However, Godoong (2016) stated that the Shannon index decreases with increasing dbh in both lowland and hill dipterocarp forests. Based on Odum and Barrett (2004) criteria, Kinarum PF is classified as moderate forest $(1<\mathrm{H}$ $<3)$. The $\mathrm{H}$ index value in Kinarum PF does not differ greatly from the results of Godoong's research (2016) in selectively logged forest of Sabah which shows the value of $\mathrm{H}<2$ for plants that have dbh above $20 \mathrm{~cm}$ and in dryland forest, Kendawangan Nature Reserve has a value of H only 2.7 (Purwaningsih and Kartawinata 2018).

In general, the results of the species abundance index calculation can be said that for all stages of growth the results are uniform. This is indicated by the value of $\mathrm{e}$ which is not much different for each stage of trees, poles, saplings, and seedlings, each of which is 1.0, 0.6, 0.6, and 0.8 . These results indicate that the Kinarum PF condition can carry out succession well.

Meanwhile, the results of the analysis show that tree density is generally higher than other stages. The pole stage has the lowest density value compared to the sapling and seedling stages. Conditions with such structures cause the regeneration of unstable forest vegetation. Pole density which is very far from the density of the tree is very risky to maintain the continuation of certain tree generations if there is a disruption to growth in the sapling and pole stages. Some species that are community characteristics in this area are indicated by their high density or a large number of individuals compared to other species, ie at the tree stage is D. lanceolata at 30 individuals/ha, while the pole stage is Dehaasia turfosa (16.67 individuals/ha), the sapling stage is Diplospora malaccensis (15 individuals /ha), and the seedling or undergrowth stage is Tectaria incisa (145 individuals/ha). The difference in density values of each species is due to differences in reproductive ability, distribution, and adaptability to the environment. Furthermore, the vegetation with the most extensive distribution capability (highest frequency value) at this research location is the tree stage is Dryobalanops lanceolata, the pole stage is Dehaasia turfosa and Dryobalanops lanceolata, the sapling stage is Diplospora malaccensis, Aidia racemosa, and Sterculia coccinea, while the seedling stage is Tectaria incisa. This shows that Kinarum PF's habitat characteristics are quite in accordance with the characteristics of the plant, so that the plant is able to adapt well. These species are the species with the highest frequency value at each stage of their growth, which indicates the best spreadability compared to other species. Frequency is used as a parameter of vegetation that can show the distribution or distribution of plant species in ecosystems.

\section{Conservation status}

The International Union for the Conservation of Nature and Natural Resources (IUCN) and the World Wildlife Fund (WWF) estimated that up to 60,000 higher plant species could become extinct or nearly extinct by the year 2050 (Subbaiyan et al. 2014). There are 2,732 species of Indonesian plants included in the IUCN conservation status category (2020), consisting of one species Extinct/EX, two species Extinct in the Wild/EW, 125 species Critically Endangered/CR, 179 species Endangered/EN, 315 species Vulnerable/VU, 1902 species Least Concern/LC, and 208 species Data Deficient/DD. The results of vegetation analysis, 42 species $(34.7 \%)$ of 121 plant species found in Kinarum PF are included in the IUCN conservation status category (2020). This shows that $1.54 \%$ of the plant species included in the IUCN red list grow in this forest area.

The species included in the IUCN red list (Table 7) consist of eight species $(6.6 \%)$ of threatened plants, 33 species $(27.3 \%)$ LC, and one species $(0.8 \%)$ DD. These plant species belonging to the family Meliaceae ( 5 species), 
which mostly come from the genus Aglaia. Sixty species of Aglaia can be found in Borneo, and 12 species are endemic (Trimanto and Sofiah 2018), some species are beginning to be rare and are found in Kinarum PF. Other threatened plants belong to Dipterocarpaceae, Malvaceae, Rubiaceae (each 4 species), Burseraceae, Lauraceae, Moraceae, Phyllanthaceae (each 3 species), Euphorbiaceae, Leguminosae (each 2 species), and Anacardiaceae, Combretaceae, Hypericaceae, Myristicaceae, Poaceae, Rhamnaceae (one species each). Eight threatened species are Aglaia angustifolia, Artocarpus tamaran, Dracontomelon costatum, Durio dulcis, Durio kutejensis, Eusideroxylon zwageri, Myristica magnifica, and Shorea guiso. Of the eight species that are threatened, based on the stage of its growth can be described as follows, three species are at the tree stage, one species is at the tree and pole stage, one species is at the tree, pole and sapling stage, and three other species, one is only at the pole stage, one at the sapling stage and another at the seedling stage (Table 7).

Thus there are five threatened plant species in the tree stage at Kinarum PF with an average density of 1.67-3.33 specimens/ha, namely $A$. angustifolia, A. tamaran, $E$. zwageri, M. magnifica, and S. guiso (Table 7). One of them is in the endangered category, $M$. magnifica. The species is a tree used as an important plant to cure various diseases, is used as an analgesic, depressant, and anti-inflammatory agent (Padmaja et al. 2019). One other species that have an endangered category is $D$. costatum which is at the sapling stage. Growth at the sapling stage has a greater disturbance risk than at the tree stage. In 1830 Korthals collected this species from Martapura (Ganesan and Middleton 2019). Furthermore, a decline in the population of D. costatum continues to occur because this species is one of the world's commercial trade logs (Mark et al. 2014) whose distribution is limited in Indonesia, Malaysia, and Brunei. According to Mark (2017) logging of primary forest plays a significant role in deforestation which results in the loss of several species of commercial timber plants. This is also supported by Upadhaya et al. (2014) which stated that in general trees that are in a rare and threatened category are caused by over-exploitation of tree species for timber. In addition to that, the highest rates of biodiversity in the world are found in tropical regions populated by developing countries, which do not have adequate technical and financial resources to manage all these species (Borokini 2014).

The IVI value of the eight threatened plant species as mentioned above is less than $10 \%$, so it can be said that the plant is not dominating Kinarum PF. A species is considered to play a role if its IVI is $\geq 10 \%$ for the seedlings and saplings stage, whereas for poles and trees the stage is $\geq 15 \%$ (Pamoengkas et al. 2019). In total, the density of trees in this study site is 400 specimen/ha (Table $6)$. These results are not much different from the results of other studies such as Kartawinata et al. (2008) in lowland dipterocarp forest at Wanariset Samboja, East Kalimantan with a tree density of 557/ha; Sidiyasa (2009) in HL Sungai Wain, East Kalimantan, with a tree density of 532.50/ha; Haryadi (2017) in HL Telaga Kameloh, Central
Kalimantan with a tree density of 502/ha, Sudrajat and Dwiputro (2019) in the Conservation Forest of the buffer zone of the Liquid Natural Gas Industry area, East Kalimantan, obtaining a tree density of 491.75 ind/ha, whereas, in Germplasm Preservation Areas, Central Kalimantan, Pamoengkas et al. (2019) only obtained 182.5/ha. The example for comparison of densities at each growth stage in the four Kalimantan forest areas with slightly different sampling sizes is as in Table 8 below. The average tree density is below 500/ ha and pole density below 700/ha, but very different results are found in the sapling and seedling stages. This shows Kinarum PF is very poor for its regeneration rate. This condition is certainly very worrying, especially for the survival of rare, endemic and threatened plant species.

While for each threatened species, the average density is $1.67-3.33 /$ ha. Other researchers also found threatened species with low average densities such as Shorea leprosula in Berau, East Kalimantan (Saridan 2012), Dryobalanops lanceolata and A. tamaran each with only 2/ha in Forest conservation LNG, East Kalimantan (Sudrajat and Dwiputro 2019), and D. kutejensis found in very limited quantities in the Kaleka forests of Central Kalimantan (Rahu et al. 2013). However, the IUCN criteria for the CR category are if the adult tree density is 0.05 individuals/ha while for the EN and VU categories it has at least an adult tree density of 0.005 individuals/ha. The average density for A. angustifolia, A. tamaran, E. zwageri, $M$. magnifica, and $S$. guiso is more than 0.05 individuals /ha, so based on the above criteria these species in Kinarum PF are theoretically not threatened. The D. costatum, D. dulcis, and D. kutejensis which are not found in the tree stage might be threatened in the next few years. However, based on IVI values, all threatened plant species in Kinarum PF have a low IVI (IVI $\leq 2.46 \%$ ), so the presence of these plants is feared to be threatened in the future. In general, plants with high IVI have better adaptability, competitive power, and reproductive capacity compared to other plants in one particular area. Conversely, a low IVI indicates that these species are very potential to be lost from the ecosystem if there is pressure due to very small numbers, low reproductive capacity, and narrow distribution in the ecosystem (Zulkarnain et al. 2015). In general, the eight species have an IVI of less than $10 \%$ and a dominance index close to 0 (nothing dominates), so it is feared that it will be threatened in the future.

Besides threatened plants, Kinarum PF is also inhabited by at least two species of plants that are protected under Minister of Environment and Forestry Regulation No.20 Th 2018 and Republic of Indonesia Government Regulation No. 7 of 1999, namely E. zwageri and Koompassia excelsa. Eleven species have been declared as Kalimantan endemic plant (Sidiyasa 2015) namely A. tamaran, Dehaasia turfosa, Dryobalanops lanceolata, D. dulcis, D. kutejensis, Ficus uncinata, Nephelium cuspidatum, Pentace borneensis, Sarcotheca macrophylla, Shorea amplexicaulis, and Tristaniopsis whiteana. Some of the threatened, endemic, or protected species mentioned above are also found in several similar research plots. 
Table 7. Species of threatened plants found in the research area (IUCN 2020)

\begin{tabular}{|c|c|c|c|c|c|c|}
\hline \multirow{2}{*}{ Species } & \multirow{2}{*}{ Family } & \multirow{2}{*}{$\begin{array}{l}\text { IUCN } \\
\text { category }\end{array}$} & \multicolumn{4}{|c|}{ Average density (specimen/ha) } \\
\hline & & & Tree & Pole & Sapling & Under \\
\hline \multicolumn{7}{|l|}{ Threatened category } \\
\hline Aglaia angustifolia (Miq.) Miq. & Meliaceae & VU & 1.67 & - & - & - \\
\hline Artocarpus tamaran Becc. & Moraceae & VU & 1.67 & - & - & - \\
\hline Dracontomelon costatum Blume & Anacardiaceae & EN & - & - & 1.67 & - \\
\hline Durio dulcis Becc. & Malvaceae & VU & - & - & - & 1.67 \\
\hline Durio kutejensis (Hassk.) Becc. & Malvaceae & VU & - & 1.67 & - & - \\
\hline Eusideroxylon zwageri Teijsm. \& Binn. & Lauraceae & VU & 3.33 & 1.67 & - & - \\
\hline Myristica magnifica Bedd. & Myristicaceae & EN & 3.33 & 1.67 & 1.67 & - \\
\hline Shorea guiso Blume & Dipterocarpaceae & VU & 1.67 & - & - & - \\
\hline \multicolumn{7}{|l|}{ LC category } \\
\hline Aglaia elliptica (C.DC.) Blume & Meliaceae & $\mathrm{LC}$ & - & - & 1.67 & - \\
\hline Aglaia grandis Korth. ex Miq. & Meliaceae & $\mathrm{LC}$ & 1.67 & - & - & - \\
\hline Aglaia simplicifolia (Bedd.) Harms & Meliaceae & $\mathrm{LC}$ & 1.67 & - & - & - \\
\hline Aidia racemosa (Cav.) Tirveng. & Rubiaceae & $\mathrm{LC}$ & 5.00 & 3.33 & 10.00 & 15.00 \\
\hline Aleurites moluccanus (L.) Willd. & Euphorbiaceae & $\mathrm{LC}$ & 1.67 & - & - & - \\
\hline Alphitonia excelsa (Fenzl) Reissek ex Benth. & Rhamnaceae & $\mathrm{LC}$ & 1.67 & - & - & - \\
\hline Antidesma montanum Blume & Phyllanthaceae & $\mathrm{LC}$ & 11.67 & 5.00 & 6.67 & 3.33 \\
\hline Antidesma stipulare Blume & Phyllanthaceae & $\mathrm{LC}$ & - & - & 5.00 & - \\
\hline Archidendron ellipticum (Blanco) I.C. Nielsen & Leguminosae & $\mathrm{LC}$ & 6.67 & 1.67 & - & - \\
\hline Artocarpus elasticus Reinw. ex Blume & Moraceae & $\mathrm{LC}$ & 1.67 & 1.67 & - & - \\
\hline Beilschmiedia kunstleri Gamble & Lauraceae & $\mathrm{LC}$ & 28.33 & - & - & - \\
\hline Bridelia tomentosa Blume & Phyllanthaceae & $\mathrm{LC}$ & - & - & 1.67 & - \\
\hline Canarium asperum Benth. & Burseraceae & $\mathrm{LC}$ & - & - & - & 1.67 \\
\hline Cratoxylum formosum (Jacq.) Benth. \& Hook.f. ex Dyer & Hypericaceae & $\mathrm{LC}$ & - & - & - & 1.67 \\
\hline Dacryodes incurvata (Engl.) H.J. Lam & Burseraceae & $\mathrm{LC}$ & 1.67 & - & - & - \\
\hline Dryobalanops lanceolata Burck & Dipterocarpaceae & $\mathrm{LC}$ & 30.00 & 8.33 & 5.00 & 1.67 \\
\hline Ficus variegata Blume & Moraceae & $\mathrm{LC}$ & 1.67 & 1.67 & - & 1.67 \\
\hline Harpullia cupanioides Roxb. & Sapindaceae & $\mathrm{LC}$ & - & - & 1.67 & - \\
\hline Koompassia excelsa (Becc.) Taub. & Leguminosae & $\mathrm{LC}$ & 1.67 & - & 5.00 & 10.00 \\
\hline Leea indica (Burm. f.) Merr. & Vitaceae & $\mathrm{LC}$ & - & - & 3.33 & - \\
\hline Mallotus philippensis (Lam.) Müll. Arg. & Euphorbiaceae & $\mathrm{LC}$ & 1.67 & - & - & - \\
\hline Neonauclea calycina (Bartl. ex DC.) Merr. & Rubiaceae & $\mathrm{LC}$ & - & - & 3.33 & - \\
\hline Neonauclea glabra (Roxb.) Bakh.f. \& Ridsdale & Rubiaceae & $\mathrm{LC}$ & 3.33 & 1.67 & - & - \\
\hline Neonauclea lanceolata (Blume) Merr. & Rubiaceae & $\mathrm{LC}$ & 3.33 & - & 3.33 & 1.67 \\
\hline Palaquium obovatum (Griff.) Engl. & Sapotaceae & $\mathrm{LC}$ & 5.00 & - & - & - \\
\hline Pennisetum purpureum Schumach. & Poaceae & $\mathrm{LC}$ & - & - & - & 1.67 \\
\hline Santiria laevigata Blume & Burseraceae & $\mathrm{LC}$ & 5.00 & 3.33 & - & - \\
\hline Scaphium macropodum (Miq.) Beumée ex K.Heyne & Malvaceae & $\mathrm{LC}$ & - & - & - & - \\
\hline Shorea amplexicaulis P.S. Ashton & Dipterocarpaceae & $\mathrm{LC}$ & 8.33 & 5.00 & - & - \\
\hline Shorea leprosula Miq. & Dipterocarpaceae & $\mathrm{LC}$ & 3.33 & 1.67 & - & - \\
\hline Sterculia lanceolata Cav. & Malvaceae & $\mathrm{LC}$ & 6.67 & 11.67 & 5.00 & - \\
\hline Terminalia foetidissima Griff. & Combretaceae & $\mathrm{LC}$ & - & - & 1.67 & - \\
\hline Toona sureni (Blume) Merr. & Meliaceae & $\mathrm{LC}$ & 1.67 & - & - & - \\
\hline \multicolumn{7}{|l|}{ DD category } \\
\hline Cinnamomum porrectum (Roxb.) Kosterm. & Lauraceae & DD & 1.67 & - & - & - \\
\hline
\end{tabular}

Note: The categories used in table 7 are global IUCN categories, not the results of the author's own assessment. CR: Critically Endangered; EN: Endangered; VU: Vulnerable; LC: Least Concern; DD: Data Deficient

Table 8. Comparison of plant density for each stage of growth in four different forest areas

\begin{tabular}{|c|c|c|c|c|c|}
\hline \multirow{2}{*}{ Location } & \multirow{2}{*}{$\begin{array}{l}\text { Plot } \\
\text { size } \\
\text { (ha) } \\
\end{array}$} & \multicolumn{4}{|c|}{ Density (specimen/ha) } \\
\hline & & Tree & Pole & Sapling & Seedling \\
\hline Kinarum Protected Forest, South Kalimantan (this research) & 0.6 & 400 & 135 & 188,33 & 330 \\
\hline Germplasm Preservation Areas, Central Kalimantan (Pamoengkas et al. 2019) & 1 & 182. & 325 & 1460 & 22875 \\
\hline Forest conservation LNG, East Kalimantan (Sudrajat \& Dwiputro. 2019) & 2 & 491 & No data & 3725 & 69218 \\
\hline Sentarum Lake National Park, West Kalimantan (Kusmana et al. 2009) & 0.1 & 390 & 670 & 6010 & No data \\
\hline
\end{tabular}


The following are a few examples: Cratoxylum formosum and A. tamaran, found in Semboja Lestari, East Kalimantan (Yassir and Arbainsyah 2014) and in Muara Kendawangan Nature Reserve, West Kalimantan (Purwaningsih and Kartawinata 2018); Tristaniopsis whiteana found in Muara Kendawangan Nature Reserve, West Kalimantan (Purwaningsih and Kartawinata 2018); D. dulcis and D. kutejensis found in Wanariset Semboja, East Kalimantan (Kartawinata et al. 2008); S. guiso found in Sebangau forest, Central Kalimantan (Mirmanto 2010); Shorea leprosula found in Besiq Bermai (Sofiah et al. 2018) and Semboja Lestari (Yassir and Arbainsyah 2014), East Kalimantan, while E. zwageri are found in some areas of East Kalimantan such as in Kutai National park (Haryati et al. 2011), Semboja Lestari (Yassir and Arbainsyah 2014), Wanariset Semboja (Kartawinata et al. 2008), HL Sungai Wain (Sidiyasa 2009), and Besiq Bermai (Sofiaht et al. 2018).

All of these species are assets of flora diversity in Kinarum PF which are feared that they will be threatened in the future if adequate conservation efforts are not conducted. Furthermore, Pamoengkas et al. (2018) stated that the loss of biological diversity threatens the sustainability and development of forests ecosystem in the future.

\section{ACKNOWLEDGEMENTS}

The author thanks to the South Kalimantan Province Forestry Service for granting permission to enter the Kinarum forest area; Director of Banua Botanic Garden and his staff, and staff of Environment and Forestry Research Development Center which have assisted in the field; Research Center for Plant Conservation and Botanical Gardens, LIPI, Bogor, Indonesia which has assigned a team and funded this activity.

\section{REFERENCES}

Almulqu AA, Arpornpong N, Boonyanuphap J. 2018. Tree species composition and structure of dry forest in Mutis Timau Protected Forest Management Unit of East Nusa Tenggara, Indonesia. Biodiversitas 19 (2): 496-503.

Atsbha T, Desta AB, Zewdu T. 2019. Woody species diversity, population structure, and regeneration status in the Gra-Kahsu natural vegetation, southern Tigray of Ethiopia. Heliyon 5: e01120. DOI: 10.1016/j.heliyon.2019. e01120

Austin KG, Schwantes A, Gu Y, Kasibhatla PS. 2019. What causes deforestation in Indonesia? Environ Res Lett 14: 024007. DOI: 10.1088/1748-9326/aaf6db

Barbour GM, Burk JK, Pitts WD. 1987. Terrestrial Plant Ecology. The Benyamin/Cummings Publishing Company. Inc., Los Angeles.

Basuki K, Mursyid A, Kurnain A, Suyanto. 2013. Analisis faktor penyebab dan strategi pencegahan pembalakan liar (illegal logging) di Kabupaten Tabalong. Enviro Scienteae 9: 27-43.

Bodos V, Hamidi A, Juiling S, Maryani A, Tanggaraju S. 2019 Dryobalanops lanceolata. The IUCN Red List of Threatened Species 2019: e.T33164A68070258. DOI: 10.2305/IUCN.UK.20193.RLTS.T33164A68070258.en

Borokini TI. 2014. A systematic compilation of IUCN red-listed threatened plant species in Nigeria. Intl J Environ Sci 3 (3): 104-133.
Budiharta S, Widyatmoko D, Irawati, Wiriadinata H, Rugayah, Partomihardjo T, Ismail, Uji T, Keim AP, Wilson KA. 2011. The processes that threaten Indonesian plants. Oryx 45 (2): 172-179.

Chen G, Sun W. 2018. The role of botanical gardens in scientific research, conservation, and citizen science. Plant Divers 40 (4): 181-188

Chong KY, Tan HTW, Corlett RT. 2009. A Checklist of the Total Vascular Plant Flora of Singapore: Native, Naturalised and Cultivated Species. Raffles Museum of Biodiversity Research, National University of Singapore, Singapore.

de Kok RPJ. 2017. Two new records of Litsea (Lauraceae) from Singapore and the lectotypification of twenty-two names from several Lauraceae genera. Gard Bull Sing 69 (2): 167-177.

Delprete PG, Jardim JG. 2012. Systematics, taxonomy and floristics of Brazilian Rubiaceae: an overview about the current status and future challenges. Rodriguésia 63 (1): 101-128.

Dosmann M, Groove A. 2012. The importance of living botanical collections for plant biology and the "next generation" of evo-devo research. Front Plant Sci 3 (137): 1-8.

Edwin M, Sulistyorini IS, Allo JK. 2017. Assessment of natural resources and local community participation in nature-based tourism of Wehea Forest, East Kalimantan. Jurnal Manajemen Hutan Tropika 23 (3): 128-139. [Indonesian]

Ganesan SK, Middleton DJ. 2019. Proposal to conserve the name Dracontomelon (Anacardiaceae) with a conserved type. Taxon 68 (4): 861-862.

Godoong E. 2016. Dynamics of Forest Structure, Tree Aboveground Carbon and Dipterocarpaceae Seedlings Growth in Selectively Logged Forest of Sabah, Malaysian Borneo. [Dissertation]. Faculty of Science, University of Zurich, Switzerland.

Goh MPY, Basri AM, Yasin H, Ahmad N. 2017. Ethnobotanical review and pharmacological properties of selected medicinal plants in Brunei Darussalam: Litsea elliptica, Dillenia suffruticosa, Dillenia excelsa, Aidia racemosa, Vitex pinnata and Senna alata. Asian Pac J Trop Biomed 7 (2): 173-180.

Granados A, Brodie JF, Bernard H, O’brien MJ. 2017. Defaunation and habitat disturbance interact synergistically to alter seedling recruitment. Ecol Appl 27 (7): 2092-2101.

Haryadi 2017. Struktur dan komposisi vegetasi pada Kawasan Lindung Air Terjun Telaga Kameloh Kabupaten Gunung Mas. Ziraa'ah 42 (2): 137-149.

Haryati JR, Intan N, Azizah IN, Arisoesilaningsih E. 2011. Eusideroxylon zwageri (Ulin) as key species in two zones of Sangkima Rain Forest, Kutai National Park, East Kalimantan. J Trop Life Sci 1 (1): 47-50.

Heriyadi. 2016. Rencana Pengelolaan Hutan Jangka Panjang Kesatuan Pengelolaan Hutan Produksi (KPHP) Model Tabalong Kabupaten Tabalong Provinsi Kalimantan Selatan (2016-2025). KPHP Model Tabalong. Dinas Kehutanan Provinsi Kalimantan Selatan. [Indonesian]

Heywood VH. 2011. The role of botanic gardens as resource and introduction centres in the face of global change. Biodiv Conserv 20: 221-239.

Ismail SA, Ghazoul J, Ravikanth G, Kushalappa CG, Shaanker RU. 2014. Forest trees in human modified landscapes: Ecological and genetic drivers of recruitment failure in Dysoxylum malabaricum (Meliaceae). PLoS ONE 9 (2): e89437. DOI: 10.1371/journal.pone.0089437

Itoh A, Yamakura T, Ogino K, Seng LH. 1995. Survivorship and growth of seedlings of four dipterocarp species in a tropical rainforest of Sarawak, East Malaysia. Ecol Res 10 (3): 327-338.

IUCN. 2020. The IUCN Red List of Threatened Species. Version 2019-3. https: //www.iucnredlist.org [13 February 2020]

IUCN. 2019. The IUCN Red List of Threatened Species. Version 2018-3. www.iucnredlist.org [10 February 2019]

IUCN. 2018. The IUCN Red List of Threatened Species. Version 2017-3. www.iucnredlist.org [28 February 2018]

IUCN/SSC. 2014. Guidelines on the use of ex situ management for species conservation, Version 2.0. IUCN Species Survival Commission, Gland, Switzerland.

IUCN. 2012. IUCN Red List Categories and Criteria: Version 3.1. 2nd ed. IUCN, Gland, Switzerland and Cambridge, UK.

Julia S, Soepadmo E, Yahud W. 2009. Problem in the generic delimitation between Alseodaphne, Dehaasia and Nothaphoebe (Lauraceae) in Borneo. Blumea 54: 192-197.

Kartawinata K, Purwaningsih, Partomihardjo T, Yusuf R, Abdulhadi R, Riswan S. 2008. Floristics and structure of a lowland Dipterocarp 
Forest at Wanariset Samboja, East Kalimantan, Indonesia. Reinwardtia 12 (4): 301-323

Karyati, Ipor IB, Jusoh I, Effendi M, Wasli, Seman IA. 2013 Composition and diversity of plant seedlings and saplings at early secondary succession of Fallow Lands in Sabal, Sarawak. Acta Biol Malays 2 (3): 85-94.

Kessler M, Keßler PJA, Gradstein SR, Bach K, Schmull M, Pitopang R. 2005. Tree diversity in primary forest and different land use systems in Central Sulawesi, Indonesia. Biodiv Conserv 14: 547-560.

Komara LL, Choesin DN, Syamsudin TS. 2016. Plant diversity after sixteen years post-coal mining in East Kalimantan, Indonesia. Biodiversitas 17 (2): 531-538.

Krebs CJ. 1999. Ecological Methodology. Harper Collins Publisher, Inc. New York.

Krishnan S, Novy A. 2016. The role of botanic gardens in the twenty-first century. CAB Reviews 11 (23): 1-10

Kuaraksa C, Elliott S, Hossaert-Mckey M. 2012. The phenology of dioecious Ficus spp. tree species and its importance for forest restoration projects. For Ecol Manag 265: 82-93.

Kusmana C, Saharjo BH, Sumawinata B, Onrizal, Kato T. 2009. Komposisi jenis dan struktur hutan hujan tropika dataran rendah di Taman Nasional Danau Sentarum, Kalimantan Barat. Jurnal Ilmu Pertanian Indonesia 14 (3): 149-157. [Indonesian]

Kuspradini H, Putri AS, Mitsunaga T. 2018. Chemical composition, antibacterial and antioxidant activities of essential oils of Dryobalanops lanceolata Burck. leaf. Res J Med Plants 12 (1): 19-25.

Laurance WF, Sayer J, Cassman KG. 2014. Agricultural expansion and its impacts on tropical nature. Trends Ecol Evol 29 (2): 107-116.

Lee SH, Ng ABC, Ong KH. 2013. The status and distribution of Ficus hispida L.f. (Moraceae) in Singapore. Nat Sing 6: 85-90.

Ling CY, Julia S. 2012. Diversity of the tree flora in Semenggoh Arboretum, Sarawak, Borneo Gard Bull Sing 64 (1): 139-169.

Magurran AE. 1988. Ecological Diversity and its Measurement. Princeton University Press, Princeton, NJ.

Mark J, Newton AC, Oldfield S, Rivers M. 2014. The International Timber Trade: A Working List of Commercial Timber Tree Species. Botanic Gardens Conservation International. Richmond, UK.

Mark JK. 2017. Applications of the IUCN Red List in Evaluating Global Extinction Risk of Timber Tree Species. [Thesis]. Bournemouth University, UK.

McGowan PJK, Holzer KT, Leus K. 2017. IUCN Guidelines for determining when and how ex situ management should be used in species conservation. Conserv Lett 10 (3): 361-366

Mirmanto E. 2010. Vegetation analyses of Sebangau Peat Swamp Forest, Central Kalimantan. Biodiversitas 11 (2): 82-88.

Mounce R, Smith P, Brockington S. 2017. Ex-situ conservation of plant diversity in the world's botanic gardens. Nature Plants 3: 795-802.

Mueller-Dumbois D, Ellenberg H. 1974. Aims and methods of vegetation ecology. John Willey and Sons, New York.

Neo L, Yee ATK, Chong KY. Tan HTW. 2014. The vascular plant flora of upper Thomson Forest. Nat Sing 7: 55-68.

Nishida S. 2008. Taxonomic revision of Beilschmiedia (Lauraceae) in Borneo. Blumea 53: 345-383.

Odum EP, Barrett GW. 2004. Fundamentals of Ecology, 5th ed. Thomson Brooks/Cole, Belmont, CA.

Padmaja V, Amgoth SN, Chinna EM. 2019. Evaluation of pharmacological activities of leaves and bark of Myristica fatua var magnifica extracts. Iranian J Pharma Sci 15 (1): 39-50.

Pamoengkas P, Siregar IZ, Dwisutono AN. 2018. Stand structure and species composition of merbau in logged-over forest in Papua, Indonesia. Biodiversitas 19 (1): 163-171.

Pamoengkas P, Zamzam A, Dwisutono A. 2019. Vegetation recovery of logged-over Dipterocarp Forests In Central Kalimantan, Indonesia. Floresta e Ambiente 26 (3): e20171239. DOI: 10.1590/21798087.123917.

Premavani D, Naidu MT, Venkaiah M. 2014. Tree species diversity and population structure in the tropical forests of north-central Eastern Ghats, India. Not Sci Biol 6 (4): 448-453.

Purwaningsih, Kartawinata K. 2018. Species composition and structure of forests in The Muara Kendawangan Nature Reserve, WestKalimantan, Indonesia. IOP Conf. Series: Earth and Environmental Science 166 (2018) 012005. DOI: 10.1088/1755-1315/166/1/012005

Raes N, Roos MC, Slik JWF, van Loon EE, ter Steege H. 2009. Botanical richness and endemicity patterns of Borneo derived from species distribution models. Ecography 32: 180-192.
Rahmah, Kartawinata K, Nisyawati, Wardhana W, Nurdin E. 2016. Tree species diversity in the lowland forest of the core zone of the Bukit Duabelas National Park, Jambi, Indonesia 2016. Reinwardtia 15 (1): $11-26$

Rahu AA, Hidayat K, Ariyadi M, Hakim L. 2013. Ethnoecology of Kaleka: Dayak's Agroforestry in Kapuas, Central Kalimantan Indonesia. Res J Agric For Sci 1 (8): 5-12

Sadeghi SM. Hanum F, Razali W, Kudus WMIK, Hakeem KR. 2014. Tree composition and diversity of a Hill Dipterocarp Forest after logging. Malayan Nat J 66 (4): 1-15.

Sadili A, Kartawinata K. 2016. A study of the undergrowth vegetation of Sempu Island, East Java, Indonesia. Reinwardtia 15 (1): 1-9.

Santoso EA, Jumari, Utami S. 2018. Inventory and biodiversity medicinal plants of Dayak Tomun society in Lopus Village, Lamandau Regency central Kalimantan. IOP Conf. Series: J Physics Conf Series 1217 (2019): 012171 DOI: 10.1088/1742-6596/1217/1/012171

Saridan A. 2012. Keragaman jenis dipterokarpa dan potensi pohon penghasil minyak keruing di hutan dataran rendah Kabupaten Berau, Kalimantan Timur. Dipterokarpa 6 (2): 75-83.

Schwartz KR, Parsons ECM, Rockwood L, Wood TC. 2017. Integrating in-Situ and ex-Situ data management processes for biodiversity conservation. Front. Ecol. Evol 5: 120. DOI: $10.3389 /$ fevo. 2017.00120

Sidiyasa K. 2009. Struktur dan komposisi tegakan serta keanekaragamannya di Hutan Lindung Sungai Wain, Balikpapan, Kalimantan Timur. Jurnal Penelitian Hutan dan Konservasi Alam 6 (1): 79-93. [Indonesian]

Sidiyasa K. 2015. Jenis-jenis pohon endemik Kalimantan. Balai Penelitian Teknologi Konservasi Sumber Daya Alam, Balikpapan. [indonesian]

Sofiah S, Metusala D, Trimanto, Nurfadilah S. 2018. Flora diversity, composition and ecology in Besiq Bermai Tropical Forest of Damai District, East Kalimantan. Biotropia 25 (2): 85-94

Sri-Ngernyuang K, Kanzaki M, Mizuno T, Oguchi H, Teejuntuk S, Sungpalee C, Hara M, Yamakura T, Sahunalu P, Dhanmanonda P, Bunyavejchewin S. 2003. Habitat differentiation of Lauraceae species in a tropical lower montane forest in northern Thailand. Ecol Res 18: 1-14

Subbaiyan B, Samydurai P, Prabu MK, Ramakrishnan R, Thangapandian V. 2014. Inventory of rare, endangered and threatened (RET) plant species in Maruthamalai Hills, Western Ghats of Tamilnadu, South India. Our Nature 12 (1): 37-43.

Sudrajat, Dwiputro M. 2019. A comparative study of tree community structure and natural regeneration status in Bontang urban forest and conservation forest of the LNG Industrial Plant Area, East Kalimantan, Indonesia. Biodiversitas 20 (10): 2841-2847.

Sukara E. 2014. Tropical forest biodiversity to provide food, health and energy solutions of the rapid growth of modern society. Procedia Environ Sci 20: 803-808.

Sunarmi, Hidayat JW, Muhammad F. 2018. Vegetation analysis of the waterfalls Curug Sewu in village Curug Sewu subdistrict Patean Kendal Regency. IOP Conf. Series: Journal of Physics: 1217 (2019): 012181. DOI: $10.1088 / 1742-6596 / 1217 / 1 / 012181$

Susanto D, Ruchiyat D, Sutisna M, Amirta R. 2016. Soil and leaf nutrient status on growth of Macaranga gigantea in secondary forest after shifting cultivation in East Kalimantan, Indonesia. Biodiversitas 17 (2): 409-416

Tirkaamiana MT, Partasasmita R, Kamarubayana 1. 2019. Growth patterns of Shorea leprosula and Dryobalanops lanceolata in Borneo's forest managed with selective cutting with line replanting system. Biodiversitas 20 (4): 1160-1165.

Todou G, Dedangsou S, Ibrahima A. 2018. Evaluation of structure and natural regeneration status of woody plant species in Sudanian domain: Case of eastern part of National Park of Sena Oura, Chad. Int J Environ Agric Biotechnol 3 (5): 1571-1581.

Toma T, Warsudi, Osone Y, Sutedjo, Sato T, Sukartiningsih. 2017. Sixteen years of changes in tree density and aboveground biomass of a logged and burned Dipterocarp Forest in East Kalimantan, Indonesia. Biodiversitas 18 (3): 1159-1167.

Trimanto, Sofiah S. 2018. Exploration of flora diversity and recommending species for reclamation of coal mining with biodiversity concept in Besiq Bermai Forest, East Borneo. J Trop Life Sci 8 (2): 97-107.

Upadhaya K, Choudhury G, Sarma K. 2014. Anthropogenic threats and plant diversity conservation in Cherrapunji-one of the wettest places on Earth. Keanean J Sci 3: 3-20. 
von Rintelen K, Arida E, Hauser C. 2017. A review of biodiversity-related issues and challenges in megadiverse Indonesia and other Southeast Asian countries. Research Ideas and Outcomes 3: e20860. DOI: 10.3897/rio.3.e20860

Widiyatno, Budiadi, Suryanto P, Rinarno YDBM, Prianto SD, Hendro Y, Hosaka T, Numata S. 2017. Recovery of vegetation structure, soil nutrients and late-succession species after shifting cultivation in Central Kalimantan, Indonesia. J Trop For Sci 29 (2): 151-162.

Yassir I, Arbainsyah. 2014. Diversity of plant communities in secondary succession of Imperata grasslands in Samboja Lestari, East Kalimantan, Indonesia. Indon J For Res 1 (2): 139-149.
Zhang L, Zhang LB. 2017. A classification of the fern genus Tectaria (Tectariaceae: Polypodiales) based on molecular and morphological evidence. Ann Missouri Bot Garden 103 (2): 188-199.

Zhang L, Zhou XM, Chen DK, Schuettpelz E, Knapp R, Lu NT, Luong TT, Dang MT, Duan YF, He H, Gao XF, Zhang LB. 2017. A global phylogeny of the fern genus Tectaria (Tectariaceae: Polypodiales) based on plastid and nuclear markers identifies major evolutionary lineages and suggests repeated evolution of free venation from anastomosing venation. Mol Phylogenetics Evol 114: 295-333

Zulkarnaen, Kasim S, Hamid H. 2015. Vegetation analysis and visualization of vegetation structure Baruga Urban Forest, Kendari City. Jurnal Hutan Tropis 3 (2): 99-109. 
Table S1. List of plants found in observation plots in Kinarum PF

\begin{tabular}{|c|c|c|c|c|c|}
\hline \multirow[b]{2}{*}{ Species name } & \multirow[b]{2}{*}{ Family } & \multicolumn{4}{|c|}{ Conservation Status } \\
\hline & & $\begin{array}{c}\text { IUCN } \\
\text { Category } \\
(2020) \\
\end{array}$ & $\begin{array}{c}\text { National } \\
\text { Protected } \\
\text { plant }\end{array}$ & $\begin{array}{c}\text { Endemic } \\
\text { of Borneo }\end{array}$ & $\begin{array}{c}E x \text {-situ } \\
\text { conservation } \\
\text { in BBG }\end{array}$ \\
\hline Actinodaphne gullavara (Buch.-Ham. ex Nees) M.R.Almeida & Lauraceae & - & - & - & - \\
\hline Aglaia angustifolia (Miq.) Miq. & Meliaceae & VU & - & - & - \\
\hline Aglaia elliptica (C.DC.) Blume & Meliaceae & $\mathrm{LC}$ & - & - & + \\
\hline Aglaia grandis Korth. ex Miq. & Meliaceae & $\mathrm{LC}$ & - & - & + \\
\hline Aglaia simplicifolia (Bedd.) Harms & Meliaceae & $\mathrm{LC}$ & - & - & + \\
\hline Aidia racemosa (Cav.) Tirveng. & Rubiaceae & $\mathrm{LC}$ & - & - & - \\
\hline Aleurites moluccanus (L.) Willd. & Euphorbiaceae & $\mathrm{LC}$ & - & - & + \\
\hline Alphitonia excelsa (Fenzl) Reissek ex Benth. & Rhamnaceae & $\mathrm{LC}$ & - & - & - \\
\hline Alstonia angustiloba Miq. & Apocynaceae & - & - & - & + \\
\hline Antidesma montanum Blume & Phyllanthaceae & $\mathrm{LC}$ & - & - & + \\
\hline Antidesma stipulare Blume & Phyllanthaceae & $\mathrm{LC}$ & - & - & + \\
\hline Archidendron ellipticum (Blanco) I.C.Nielsen & Leguminosae & $\mathrm{LC}$ & - & - & + \\
\hline Artocarpus elasticus Reinw. ex Blume & Moraceae & $\mathrm{LC}$ & - & - & + \\
\hline Artocarpus integer (Thunb.) Merr. & Moraceae & - & - & - & + \\
\hline Artocarpus lacucha Buch.-Ham. & Moraceae & - & - & - & + \\
\hline Artocarpus lanceifolius Roxb. & Moraceae & - & - & - & - \\
\hline Artocarpus tamaran Becc. & Moraceae & VU & - & + & + \\
\hline Beilschmiedia kunstleri Gamble & Lauraceae & LC & - & - & + \\
\hline Blumeodendron sp. & Lauraceae & - & - & - & - \\
\hline Bridelia insulana Hance & Euphorbiaceae & - & - & - & + \\
\hline Bridelia tomentosa Blume & Euphorbiaceae & $\mathrm{LC}$ & - & - & + \\
\hline Buchanania arborescens (Blume) Blume & Anacardiaceae & - & - & - & + \\
\hline Calathea zebrina (Sims) Lindl. & Marantaceae & - & - & - & + \\
\hline Canarium asperum Benth. & Burseraceae & $\mathrm{LC}$ & - & - & + \\
\hline Canthium glabrum Blume & Rubiaceae & - & - & - & - \\
\hline Cheilocostus speciosus (J.Koenig) C.D.Specht & Costaceae & - & - & - & + \\
\hline Cinnamomum porrectum (Roxb.) Kosterm. & Lauraceae & DD & - & - & + \\
\hline Clausena excavata Burm.f. & Rutaceae & - & - & - & + \\
\hline Connarus odoratus & Connaraceae & - & - & - & - \\
\hline Cratoxylum formosum (Jacq.) Benth. \& Hook.f. ex Dyer & Hypericaceae & $\mathrm{LC}$ & - & - & + \\
\hline Cryptocarya ferrea Blume & Lauraceae & - & - & - & + \\
\hline Cryptocarya strictifolia Kosterm. & Lauraceae & - & - & - & - \\
\hline Dacryodes incurvata (Engl.) H.J.Lam & Burseraceae & $\mathrm{LC}$ & - & - & - \\
\hline Daemonorops laciniata Furtado & Arecaceae & - & - & - & - \\
\hline Dehaasia cuneata (Blume) Blume & Lauraceae & - & - & - & - \\
\hline Dehaasia incrassata (Jack) Kosterm. & Lauraceae & - & - & - & + \\
\hline Dehaasia turfosa Kosterm. & Lauraceae & - & - & + & - \\
\hline Diospyros borneensis Hiern & Ebenaceae & - & - & - & + \\
\hline Diospyros macrophylla Blume & Ebenaceae & - & - & - & + \\
\hline Diplospora malaccense Hook. $\mathrm{f}$. & Rubiaceae & - & - & - & + \\
\hline Dracontomelon costatum Blume & Anacardiaceae & $\mathrm{EN}$ & - & - & - \\
\hline Dryobalanops lanceolata Burck & Dipterocarpaceae & $\mathrm{LC}$ & - & + & + \\
\hline Durio dulcis Becc. & Malvaceae & VU & - & + & + \\
\hline Durio kutejensis (Hassk.) Becc. & Malvaceae & VU & - & + & + \\
\hline Dysoxylum sp. & Meliaceae & - & - & - & - \\
\hline Elaeocarpus stipularis Blume & Elaeocarpaceae & - & - & - & + \\
\hline Elateriospermum tapos Blume & Euphorbiaceae & - & - & - & + \\
\hline Endiandra sp. & Lauraceae & - & - & - & - \\
\hline Eusideroxylon zwageri Teijsm. \& Binn. & Lauraceae & VU & + & - & + \\
\hline Ficus consociata Blume & Moraceae & - & - & - & + \\
\hline Ficus ribes Reinw. ex Blume & Moraceae & - & - & - & - \\
\hline Ficus serrata L. & Moraceae & - & - & - & - \\
\hline Ficus sp. & Moraceae & - & - & - & - \\
\hline Ficus uncinata (King) Becc. & Moraceae & - & - & + & - \\
\hline Ficus variegata Blume & Moraceae. & $\mathrm{LC}$ & - & - & - \\
\hline Gluta renghas L. & Anacardiaceae & - & - & - & + \\
\hline Guioa diplopetala (Hassk.) Radlk. & Sapindaceae & - & - & - & + \\
\hline Guioa pleuropteris (Blume) Radlk. & Sapindidanceae & - & - & - & + \\
\hline Gymnacranthera forbesii (King) Warb. & Myristicaceae & - & - & - & + \\
\hline Harpullia cupanioides Roxb. & Sapindaceae & $\mathrm{LC}$ & - & - & - \\
\hline Koompassia excelsa (Becc.) Taub. & Leguminosae & $\mathrm{LC}$ & + & - & + \\
\hline
\end{tabular}


Lansium parasiticum (Osbeck) K.C.Sahni \& Bennet Leea indica (Burm. f.) Merr.

Leucosyke capitellata Wedd.

Lithocarpus cyclophorus (Endl.) A.Camus

Lithocarpus elegans (Blume) Hatus. ex Soepadmo

Litsea garciae Vidal

Litsea umbellata (Lour.) Merr.

Lygodium circinatum (Burm. f.) Sw.

Macaranga bancana (Miq.) Müll.Arg.

Macaranga gigantea (Rchb.f. \& Zoll.) Müll.Arg.

Mallotus philippensis (Lam.) Müll.Arg.

Memecylon acuminatissimum Blume

Memecylon edule Roxb.

Memecylon oleifolium Blume

Memecylon paniculatum Jack

Myristica magnifica Bedd.

Neolamarckia cadamba (Roxb.) Bosser

Neolitsea cassiifolia Merr.

Neonauclea calycina (Bartl. ex DC.) Merr.

Neonauclea glabra (Roxb.) Bakh.f. \& Ridsdale

Neonauclea lanceolata (Blume) Merr.

Nephelium cuspidatum Blume

Nephelium juglandifolium Blume

Pennisetum purpureum Schumach.

Pentace borneensis Pierre

Peronema canescens Jack

Phyllanthus reticulatus Poir.

Pimeleodendron sp.

Polyalthia rumphii (Blume ex Hensch.) Merr.

Polyscias nodosa (Blume) Seem.

Pouteria multiflora (A.DC.) Eyma

Rauvolfia verticillata (Lour.) Baill.

Rhaphidophora hookeri Schott

Roureopsis emarginata (Jack) Merr.

Santiria laevigata Blume

Sarcotheca macrophylla Blume

Saurauia sp.

Scaphium macropodum (Miq.) Beumée ex K.Heyne

Scleria sumatrensis Retz.

Shorea amplexicaulis P.S.Ashton

Shorea guiso Blume

Shorea leprosula Miq.

Spermacoce alata Aubl.

Stachyphrynium placentarium (Lour.) Clausager \& Borchs.

Sterculia coccinea Roxb.

Sterculia lanceolata Cav.

Sterculia macrophylla Vent.

Sterculia rubiginosa Zoll. ex Miq.

Taenitis blechnoides (Willd.) Sw.

Tectaria incisa Cav.

Terminalia foetidissima Griff.

Timonius wallichianus (Korth.) Valeton

Toona sureni (Blume) Merr.

Tristaniopsis whiteana (Griff.) Peter G.Wilson \& J.T.Waterh.

Uvaria schizocalyx Backer

Vernonia arborea Buch.-Ham.

Vitex altissima L.f

Xanthophyllum vitellinum (Blume) D.Dietr.
Palaquium obovatum (Griff.) Engl.

Tetracera scandens (L.) Merr.
Meliaceae.

Vitaceae

Urticaceae

Fagaceae

Fagaceae

Lauraceae

Lauraceae

Lygodiaceae

Euphorbiaceae

Euphorbiaceae

Euphorbiaceae

Melastomataceae

Melastomataceae

Melastomataceae

Melastomataceae

Myristicaceae

Rubiaceae

Lauraceae

Rubiaceae

Rubiaceae

Rubiaceae

Sapindaceae

Sapindaceae

Sapotaceae

Poaceae

Malvaceae

Lamiaceae

Rubiaceae

Euphorbiaceae

Annonaceae

Araliaceae

Sapotaceae

Apocynaceae

Araceae

Connaraceae

Burseraceae

Oxalidaceae

Actinidiaceae

Malvaceae

Cyperaceae

Dipterocarpaceae

Dipterocarpaceae

Dipterocarpaceae

Rubiaceae

Maranthaceae

Malvaceae

Malvaceae

Malvaceae

Malvaceae

Pteridaceae

Tectariaceae

Dilleniaceae

Rubiaceae

Meliacaeae

Myrtaceae

Annonaceae

Compositae

Lamiaceae

Polygalaceae
Combretaceae

LC $\quad-\quad 20+$ 